\title{
Efek Pupuk Hayati Terhadap Serapan N (N-15) pada Fase Awal Pertumbuhan Tanaman Jagung
}

\section{Effects of Biofertilizers on $N$-uptake (N-15) of Corn (Zea mays L.) Plant at Early Growth-Stage}

\author{
Taufiq Bachtiar ${ }^{1}$, Anggi Nico Flatian ${ }^{1}$, Nurrobifahmi ${ }^{2}$, dan Setiyo Hadi \\ Waluyo $^{2}$ \\ ${ }^{1}$ Program Studi Bioteknologi Tanah dan Lingkungan \\ Departemen Ilmu Tanah dan Sumberdaya Lahan \\ Fakultas Pertanian, Institut Pertanian Bogor \\ ${ }^{2}$ Pusat Aplikasi Isotop dan Radiasi, BATAN \\ Jl. Lebak Bulus Raya No. 49 Jakarta 12440 \\ E-mail : taufiqb@batan.go.id
}

Diterima 01-04-2016; Diterima dengan revisi 19-04-2016; Disetujui 30-05-2016

\begin{abstract}
ABSTRAK
Efek Pupuk Hayati Terhadap Serapan N (N-15) pada Fase Awal Pertumbuhan Tanaman Jagung. Telah dipelajari dengan percobaan pot di rumah kaca PAIR BATAN. Inokulan mikrob Azotobacter vinelandii (A), Bacillus cereus (B), Bacillus megaterium (C), dan campuran dari ketiga jenis mikrob tersebut (ABC) digunakan sebagai pupuk hayati yang diaplikasikan pada tanaman jagung yang tumbuh dalam pot. Rancangan Acak Kelompok (RAK) dengan 4 kali ulangan digunakan dalam percobaan ini. Parameter yang diukur meliputi serapan Nitrogen $(\mathrm{N})$ tanaman, $\mathrm{N}$ berasal dari tanah, $\mathrm{N}$ berasal dari pupuk hayati dan berat kering tanaman pada 20 HST. Kandungan N berasal dari pupuk hayati dan $\mathrm{N}$ berasal dari tanah ditentukan dengan menggunakan teknik isotop $\mathrm{N}-15$. Hasil penelitian menunjukkan bahwa secara signifikan aplikasi pupuk hayati ABC meningkatkan total $\mathrm{N}$ tanaman $(142,42 \%)$ dan berat kering tanaman $(129,03 \%)$ dari kontrol. Berdasarkaan analisis dengan teknik isotop $\mathrm{N}$ - 15 menunjukkan bahwa kontribusi yang paling signifikan dalam meningkatkan $\mathrm{N}$ tanaman $(67,92 \%)$ ditemukan pada perlakuan pupuk hayati ABC.
\end{abstract}

Kata kunci : Jagung, Pupuk hayati, Nitrogen, Isotop, N-15

\begin{abstract}
Effects of Biofertilizers on N-uptake (N-15) of Corn (Zea mays L.) Plant at Early Growth-Stage. Were studied in pot experiment at the green house in PAIR-BATAN. Broth culture of Azotobacter vinelandii (A), Bacillus cereus (B), Bacillus megaterium (C), and a mixture of those three microbes (ABC) were used as biofertilizers, and applied directly on plant grown in pots. Randomized Block Design (RBD) was used in this experiment with six treatments and four replicates. The measured parameters were nitrogen $(\mathrm{N})$ uptake, $\mathrm{N}$ derived from the soil, $\mathrm{N}$ derived from fertilizer, and plant dry weight. These parameters were determined at 20 days after planting. $\mathrm{N}$ derived from biofertilizer and $\mathrm{N}$ derived from soil were determined by $\mathrm{N}-15$ isotope technique. The results showed that $\mathrm{ABC}$ treatment most significanly increase the total $\mathrm{N}$ plant $(142,42 \%)$ and plant dry weight plant $(129.03 \%)$ by the control plant. Based on $\mathrm{N}-15$ isotope technique analysis showed that the significantly contribution to increase $\mathrm{N}$ plant was found in $\mathrm{ABC}$ treatment $(67.92 \%)$.
\end{abstract}

Keywords : Corn, Biofertilizer, Nitrogen, Isotope, N-15 


\section{PENDAHULUAN}

Jagung merupakan salah satu sereal unggulan peringkat ketiga setelah gandum dan beras untuk memasok konsumsi populasi global [1]. Data angka tetap BPS tahun 2015 produksi jagung di Indonesia diperkirakan sebesar 19,61 juta ton pipilan kering atau naik sebesar 0,61 juta ton $(3,21$ persen) dibandingkan tahun 2014. Kenaikan produksi tersebut terjadi karena adanya perkiraan peningkatan produktivitas sebesar 2,36 kuintal/hektar (4,76 persen). Namun di lain sisi, luas panen produksi jagung menurun dari 3,83 juta ha pada 2014 menjadi 3,78 juta ha pada 2015 [2]. Intensifikasi perlu terus dilakukan untuk memenuhi peningkatan kebutuhan nasional dan menanggulangi penyempitan area pertanian. Dalam sistem pertanian berkelanjutan, pupuk hayati memainkan peran penting dalam meningkatkan produksi tanaman dan konservasi kesuburan tanah [3]. Oleh karena itu pengembangan dan pemakaian pupuk hayati perlu terus ditingkatkan terutama di tingkat petani.

Nitrogen adalah salah satu unsur esensial makro untuk produksi tanaman. Pertanian konvensional yang berorientasi pada hasil dan kualitas yang tinggi sangat bergantung pada penggunaan pupuk $\mathrm{N}$ kimia yang dikenal mahal dan mempunyai dampak buruk terhadap lingkungan [4]. Saat ini dampak pemupukan $\mathrm{N}$ kimia yang intensif terhadap tanah dan lingkungan semakin jelas dengan banyak ditemukannya tanah-tanah yang tidak responsif terhadap pemupukan (soil sickness). Oleh karena itu, ada kebutuhan besar untuk mencari dan memanfaatkan semua peluang secara optimal untuk meningkatkan kadar $\mathrm{N}$ tanaman yang berasal dari penambatan $\mathrm{N}_{2}$ biologis [5].

Azotobacter vinelandii, Bacillus cereus, $B$. megantherium merupakan bakteri yang hidup bebas di dalam tanah yang telah diketahui mampu menyediakan unsur hara dan hormon pertumbuhan bagi tanaman. Tinggi, diameter, dan hasil tanaman jagung meningkat tajam karena pemberian bakteri
Azospirillum dan Azotobacter dibandingkan dengan tanpa bakteri $[6,10,11]$. Aplikasi bakteri seperti Azotobacter dan Azospirillum pada biji juga dapat meningkatkan bobot kering tanaman [7], nitrogen dan kadar klorofil pada tanaman gandum $[8,9]$. Informasi tentang kapan sebenarnya pupuk hayati mulai meningkatkan serapan $\mathrm{N}$ dan berapa besar menyumbangkan unsur hara $\mathrm{N}$ masih sangat sedikit. Pupuk hayati yang diberikan kedalam tanah membutuhkan waktu untuk beradaptasi sebelum dapat berkontribusi dalam mendukung pertumbuhan tanaman. Selain itu, beberapa laporan menyebutkan bahwa membaiknya pertumbuhan tanaman bukan karena proses penambatan $\mathrm{N}_{2}$, namun karena pengaruh zat perangsang tumbuh yang diproduksi oleh pupuk hayati tersebut.

Teknik isotop ${ }^{15} \mathrm{~N}$ telah lama dikembangkan sebagai perunut untuk menentukan besaran sumbangan $\mathrm{N}$ tanaman yang berasal dari pemakaian pupuk hayati, dari tanah dan dari pupuk $\mathrm{N}$ kimia. Tujuan dari penelitian ini adalah untuk mengetahui pengaruh pemberian pupuk hayati terhadap pertumbuhan dan kontribusinya terhadap $\mathrm{N}$ tanaman jagung, tujuan lainnya adalah untuk mempelajari peranan pupuk hayati pada awal pertumbuhan tanaman jagung khususnya terhadap sumbangan $\mathrm{N}$ yang diberikan kepada tanaman sehingga dapat diketahui waktu yang tepat untuk pemberian pupuk hayati bila dibandingkan dengan urea.

\section{BAHAN DAN METODE}

\section{Waktu dan tempat penelitian}

Penelitian ini dilakukan pada bulan Juli 2013 sampai dengan Oktober 2013. Penanaman tanaman jagung dan analisis $\mathrm{N}$ 15 di laboratorium Pemupukan dan Nutrisi Tanaman dan rumah kaca Bidang Pertanian PAIR BATAN Pasar Jumat, Jakarta Selatan.

\section{Bahan}

Bahan yang digunakan meliputi ammonium sulfat $\left(\mathrm{NH}_{4}\right)_{2} \mathrm{SO}_{4}$ bertanda $\mathrm{N}-15$, 
$\mathrm{H}_{2} \mathrm{SO}_{4}$ pekat, Selenium mixture, $\mathrm{NaOH} 45 \%$, $\mathrm{HCl} 0.1 \mathrm{~N}$, Indicator Metylene Blue, $\mathrm{CaO}$, $\mathrm{CuO}$, pipa kapiler $\varnothing 2 \mathrm{~mm}$ panjang $8 \mathrm{~mm}$, tabung Pyrex $\varnothing 4 \mathrm{~mm}$ panjang $20 \mathrm{~cm}$, biakan Azotobacter vinelandii, Bacillus cereus, Bacillus megaterium, (koleksi dari lab. Kelompok Tanah dan Nutrisi Tanaman PAIR BATAN), SP-36, pupuk dasar (urea, SP-36, dan $\mathrm{KCl}$ ), benih jagung (BISI tongbes), medium Nutrien Broth (NB), larutan garam fisiologis $0.85 \%, \mathrm{HCl} 0.1 \mathrm{~N}$. Pupuk sintetis yang digunakan merupakan urea, pupuk $\mathrm{KCl}$, dan pupuk SP-36, sementara tanah yang digunakan adalah tanah Latosol asal Pasar Jumat Jakarta Selatan.

\section{Prosedur Kerja}

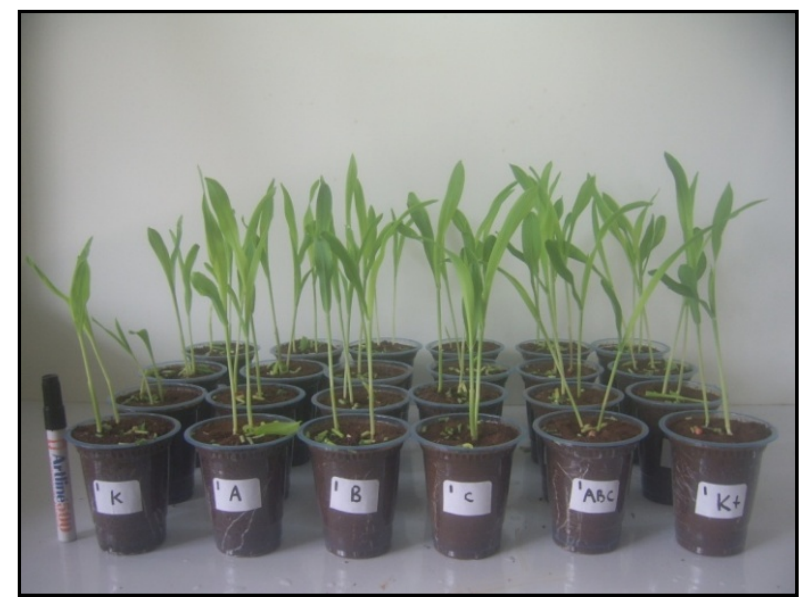

Gambar 1. Tanaman yang ditumbuhkan pada tanah Latosol Pasar Jumat

Tiga isolat (Azotobacter vinelandii, $B$. cereus dan $B$. megantherium) masing-masing diremajakan dan diperbanyak dalam erlenmeyer berisi medium cair (Nutrien Broth) $100 \mathrm{~mL}$. Inokulan cair dalam erlenmeyer tersebut dikocok dengan kecepatan $120 \mathrm{rpm}$ selama 3 hari (populasi bakteri telah mencapai $10^{8} \mathrm{sel} / \mathrm{ml}$ [ [12]. Tanah yang digunakan sebagai media tumbuh merupakan top soil Latosol Pasar Jumat yang diambil dari kebun percobaan PAIR BATAN sampai dengan kedalaman 20 $\mathrm{cm}$. Tanah dikeringanginkan, diayak sehingga lolos saring $2 \mathrm{~mm}$. Tanah kemudian ditimbang dengan berat $300 \mathrm{~g}$ dan dimasukan ke dalam wadah gelas plastik
(Gambar 1). Tanah ditandai dengan N-15 dengan cara mencampurkan secara merata ammonium sulfat bertanda sebanyak $0,1 \mathrm{~g}$ pada tanah. Inokulan diaplikasikan dengan cara diinjeksikan pada tanah yang telah ditanami benih jagung sebanyak masingmasing $5 \mathrm{~mL}$ dengan menggunakan disposable syringe steril.

Perlakuan $\mathrm{K}(+)$ merupakan pemberian pupuk urea, SP-36 dan $\mathrm{KCl}$ dengan dosis yang setara dengan $300 \mathrm{~kg} / \mathrm{ha}$ urea, 200 $\mathrm{kg} / \mathrm{ha}$ SP-36, dan $100 \mathrm{~kg} / \mathrm{ha} \mathrm{KCl}$. Rancangan percobaan yang digunakan adalah Rancangan Acak Kelompok (RAK) yang terdiri dari enam perlakuan, yang diulang sebanyak empat kali, sehingga terdapat 24 pot percobaan. $\mathrm{K}=$ Kontrol, $\mathrm{K}(+)=\mathrm{NPK}$, $\mathrm{A}=$ Azotobacter vinelandii, $\mathrm{B}=$ B.cereus, $\mathrm{C}=B$. megaterium, dan $\mathrm{ABC}(\mathrm{A}+\mathrm{B}+\mathrm{C})$. Pengujian perbedaan antar perlakuan menggunakan Uji Fisher pada taraf kepercayaan 5\%, sedangkan untuk menguji perbedaan nilai rata-rata diuji dengan Uji Jarak Berganda Duncan pada taraf 5\% [13].

\section{Berat Kering dan Serapan N}

Tanaman diamati pertumbuhannya sampai dengan panen pada 20 hari setelah tanam (HST). Setelah tanaman dipanen tanaman dicuci dengan menggunakan air mengalir hingga bersih, tanaman dikeringkan pada suhu $60^{\circ} \mathrm{C}$ selama 2 hari dan diukur berat keringnya. Sampel ditentukan kadar $\mathrm{N}$ total dengan menggunakan metode Kjeldahl [14].

\section{Pengukuran sumbangan $\mathrm{N}$ dengan teknik N-15}

Penentuan N-15 dilakukan dengan cara mengukur kandungan N-15 dalam ekstrak sampel. Ekstrak sampel hasil penentuan kadar $\mathrm{N}$ metode Kjeldahl dari masing-masing perlakuan diberi $\mathrm{HCl} 0,1 \mathrm{~N} 2$ tetes kemudian dipanaskan perlahan dan dibiarkan menguap hingga ekstrak hanya tersisa kirakira $1 \mathrm{ml}$. Ekstrak hasil penguapan dimasukan ke dalam pipa kapiler Schott Ø 2 $\mathrm{mm}$ panjang $8 \mathrm{~mm}$. Pipa kapiler dimasukan kedalam tabung Pyrex $\varnothing 4 \mathrm{~mm}$ panjang 20 $\mathrm{cm}$ diberi sedikit $\mathrm{CuO}$ dan $\mathrm{CaO}$ kemudian 
divakum hingga kedap udara dan dipanaskan dalam furnace pada suhu $400{ }^{\circ} \mathrm{C}$. Sampel dalam gelas dapat diukur dengan menggunakan spektrometri optikal emisi NOI-6PC.

\section{HASIL DAN PEMBAHASAN}

\section{Serapan N Tanaman}

Berdasarkan data statistik pada Gambar 2. menunjukkan bahwa Serapan Ntotal (N-to) untuk perlakuan A sampai dengan perlakuan $\mathrm{K}(+)$ semuanya menunjukkan pengaruh yang nyata bila dibandingkan dengan kontrol (K0). Nilai serapan $\mathrm{N}$ yang paling tinggi diperoleh pada perlakuan pupuk hayati dengan formula ABC yang mampu meningkatkan serapan $\mathrm{N}$ sebesar 142,49\% dari kontrol (K0). Perlakuan pupuk rekomendasi berupa urea hanya memberikan peningkatan terhadap kontrol sebesar 104,93\%. Pupuk hayati dengan formula A dapat meningkatkan serapan $\mathrm{N}$ dari kontrol sebanyak 23,56\%, sedangkan perlakuan B dan C yang masingmasing mampu meningkatkan serapan $\mathrm{N}$ sebesar 41,89\% dan 56,59\%. Data pada Gambar 1. juga memperlihatkan bahwa perlakuan A yang diketahui merupakan bakteri penambat $\mathrm{N}_{2}$ tidak memberikan nilai serapan $\mathrm{N}$ yang lebih tinggi dari perlakuan $\mathrm{B}$ dan C (bakteri pelarut fosfat).

Apabila digabungkan mikrob A, B, dan $\mathrm{C}$ maka akan menghasilkan nilai serapan $\mathrm{N}$ yang paling tinggi bahkan jika dibandingkan dengan nilai serapan perlakuan pupuk urea dengan dosis rekomendasi. Hal ini menunjukkan bahwa mikrob dapat bekerja sinergis segera setelah diaplikasikan pada tanah. Formula pupuk hayati ABC bekerja lebih efisien dalam menyediakan $\mathrm{N}$ untuk tanaman pada awal pertumbuhan tanaman. Hasil analisis serapan $\mathrm{N}$ diatas dapat menunjukkan bahwa mikrob dengan fungsi yang berbeda dapat diformulasikan dan bekerja sinergis di dalam tanah sehingga berpengaruh positif pada Nitrogen yang dapat diserap dan pertumbuhan tanaman.

ALEXANDER [15] menyatakan bahwa sejumlah faktor lingkungan turut mengatur tingkat dan besarnya fiksasi $\mathrm{N}_{2}$ oleh bakteri non simbiosis, dan transformasinya sangat dipengaruhi oleh karakteristik fisik dan kimia habitat tempat bakteri hidup. Perlakuan pemberian pupuk hayati ABC memberikan pengaruh yang paling tinggi terhadap serapan $\mathrm{N}$ tanaman bila dibandingkan dengan pupuk NPK rekomendasi. Hal ini membuktikan bahwa

\section{Serapan $\mathbf{N}$ (mgN/tanaman)}

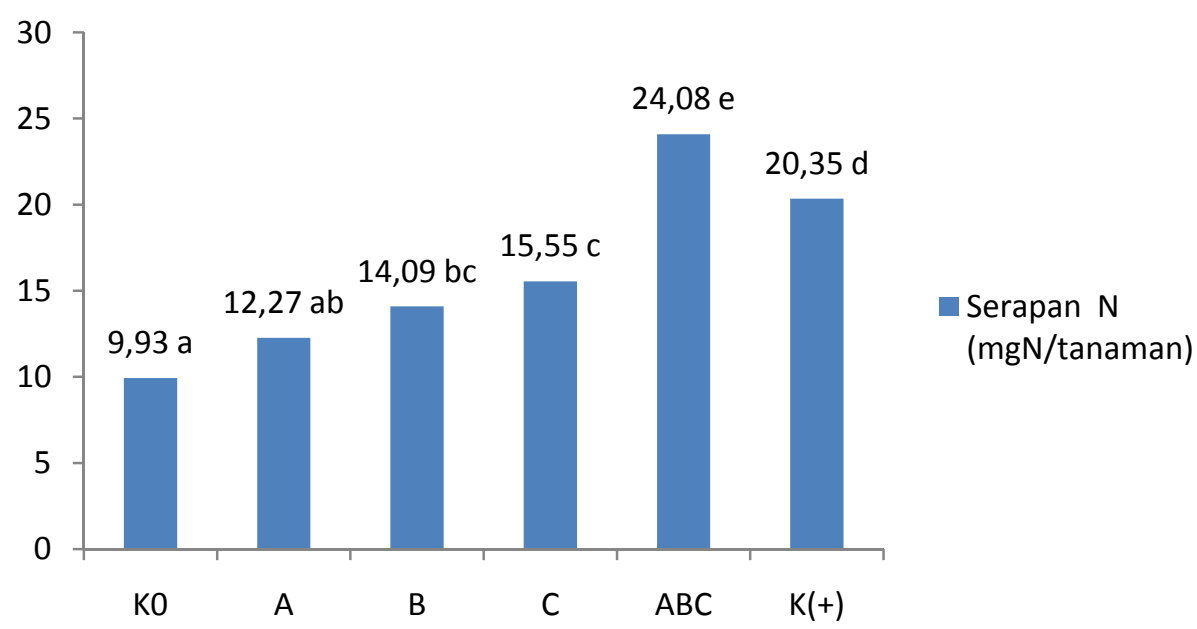

Gambar 2. Pengaruh pemberian pupuk hayati terhadap serapan $\mathrm{N}$ tanaman jagung 
mikrob fungsional dalam pupuk hayati lebih efektif bila dibandingkan dengan urea pada awal pertumbuhan tanaman jagung. Urea merupakan jenis pupuk anorganik yang cepat tersedia bagi tanaman, namun memiliki kekurangan yaitu mudah tercuci oleh air dan mudah menguap sehingga tingkat efisiensinya rendah, oleh karena itu serapan $\mathrm{N}$ pada tanaman seringkali rendah. Pupuk hayati memungkinkan lebih efisien dalam mengurangi kehilangan $\mathrm{N}$ dalam tanah, selama mikrob dalam pupuk hayati tersebut dapat hidup dan berkembang biak dengan baik. YAZDANI et al. [16] melaporkan bahwa inokulasi bakteri rhizobacteria terbukti efisien digunakan untuk meningkatkan pertumbuhan dan hasil biji tanaman jagung, meningkatkan ketersediaan hara $\mathrm{N}$, dan mengurangi kehilangan $\mathrm{N}$ karena pencucian. Jika lingkungan pada rhizosfer mendukung maka pemberian mikrob akan lebih efisien dalam meningkatkan penyerapan $\mathrm{N}$ oleh tanaman jagung pada awal pertumbuhannya.

\section{$\mathrm{N}$ berasal dari formula pupuk hayati dan $\mathbf{N}$ berasal dari tanah}

Pada penelitian ini $\mathrm{N}$ yang berasal dari pupuk adalah $\mathrm{N}$ dari mikrob $\mathrm{A}, \mathrm{B}, \mathrm{C}, \mathrm{ABC}$, atau yang berasal dari pemberian urea, sedangkan $\mathrm{N}$ yang berasal dari tanah merupakan $\mathrm{N}$ yang ada di dalam tanah. Nilai $\mathrm{N}$ berasal dari pupuk atau $\mathrm{N}$ berasal dari tanah dapat ditentukan dari besarnya persen (\%) N-15. Tanpa perlakuan K(0) memberikan nilai persentase N-15 yang lebih besar daripada perlakuan lainnya karena $\mathrm{K}(0)$ hanya akan mendapatkan sumber Nitrogen dari ammonium sulfate bertanda $\mathrm{N}-15$ yang diberikan ke dalam tanah dan $\mathrm{N}$ yang ada di dalam tanah secara alami.

Apabila persentase N-15 lebih rendah terdapat dalam jaringan tanaman daripada perlakuan lainnya maka ini menunjukkan bahwa perlakuan yang diberikan memberikan pengaruh yang paling besar terhadap serapan $\mathrm{N}$ total tanaman (Tabel 1). Perlakuan ABC menunjukkan persentase N15 lebih rendah daripada perlakuan lainnya. Sementara itu persentase N-15 dari perlakuan Kontrol $(+)$ yang dalam hal ini adalah urea, secara statistik tidak berbeda nyata $(P>0,05)$ dengan perlakuan $A B C$ hanya dengan nilai persentase $\mathrm{N}-15$ yang sedikit lebih tinggi.

Tanaman jagung yang diberi perlakuan formula pupuk hayati ABC mendapatkan sumbangan $\mathrm{N}$ lebih banyak (secara statistik berbeda pada $\mathrm{P}<0,05$ ) berasal dari formulasi pupuk hayati yang diberikan dibandingkan yang berasal dari tanah. Seperti yang telah dijelaskan diawal bahwa formula pupuk hayati yang disusun mengandung mikrob penambat $\mathrm{N}_{2}$ yang hidup bebas, sehingga $\mathrm{N}$ yang disumbangkan dalam hal ini berasal dari udara melalui fiksasi $N$. Namun $N$ di dalam tanah juga dapat berpotensi menjadi tersedia, seperti ammonium yang dapat terikat pada koloid tanah sama halnya dengan kation lainnya. Dari Tabel 1 dapat

Tabel 1. Tabel Rata-rata $\mathrm{N}$ berasal dari Pupuk Hayati dan $\mathrm{N}$ berasal dari tanah

\begin{tabular}{|c|c|c|c|c|c|c|}
\hline Perlakuan & $\begin{array}{c}\text { Serapan N } \\
\text { Total pada } \\
\text { Jagung } \\
\text { (mgN/tanam } \\
\text { an) }\end{array}$ & $\begin{array}{c}\text { Rata-rata } \\
\mathrm{N}^{15}(\%) \\
\text { yang } \\
\text { diserap } \\
\text { tanaman }\end{array}$ & $\begin{array}{c}\text { Rata-rata } \\
\text { Kontribusi } \\
\text { N dari } \\
\text { Perlakuan } \\
(\%)\end{array}$ & $\begin{array}{c}\text { N- berasal } \\
\text { dari Tanah } \\
\qquad(\%)\end{array}$ & $\begin{array}{c}\text { N-berasal } \\
\text { dari } \\
\text { Perlakuan } \\
\text { (mgN/tanam } \\
\text { an) }\end{array}$ & $\begin{array}{l}\text { N-berasal dari } \\
\text { tanah } \\
\text { (mgN/tanaman) }\end{array}$ \\
\hline Kontrol (-) & $9,93^{a}$ & $19,32^{\mathrm{c}}$ & $0^{\mathrm{a}}$ & $100^{f}$ & $0,00^{\mathrm{a}}$ & $9,93^{b c}$ \\
\hline A & $12,27^{\mathrm{ab}}$ & $13,34^{\mathrm{b}}$ & $36,63^{c}$ & $63,37^{\mathrm{d}}$ & $4,49^{b}$ & $7,79^{\mathrm{ab}}$ \\
\hline B & $14,09^{b c}$ & $9,82^{\mathrm{a}}$ & $56,14^{\mathrm{e}}$ & $43,86^{b}$ & $7,81^{\mathrm{c}}$ & $6,28^{\mathrm{a}}$ \\
\hline $\mathrm{C}$ & $15,55^{\mathrm{c}}$ & $15,92^{\mathrm{b}}$ & $20,06^{b}$ & $79,94^{\mathrm{e}}$ & $3,07^{b}$ & $12,48^{\mathrm{c}}$ \\
\hline $\mathrm{ABC}$ & $24,08^{\mathrm{e}}$ & $8,61^{\mathrm{a}}$ & $67,92^{\mathrm{f}}$ & $32,07^{\mathrm{a}}$ & $16,28^{\mathrm{e}}$ & $7,79^{\mathrm{ab}}$ \\
\hline Kontrol $(+)$ & $20,35^{\mathrm{d}}$ & $9,57^{\mathrm{a}}$ & $46,46^{d}$ & $53,54^{\mathrm{c}}$ & $9,49^{\mathrm{d}}$ & $10,87^{\mathrm{bc}}$ \\
\hline
\end{tabular}

Keterangan : Huruf superscript yang berbeda pada kolom yang sama berbeda nyata $(\mathrm{P}<0,05)$. 
diketahui bahwa meskipun perlakuan $\mathrm{ABC}$ memberikan sumbangan $\mathrm{N}$ secara nyata $(\mathrm{P}<0,05)$, tanah juga tetap memberikan sumbangan terhadap $\mathrm{N}$ total tanaman secara nyata $(\mathrm{P}<0,05)$. Bahkan pada perlakuan lainnya $\mathrm{N}$ yang berasal dari tanah memberikan sumbangan $\mathrm{N}$ yang lebih tinggi bila dibandingkan perlakuan lainnya. Hal ini menunjukkan bahwa $\mathrm{N}$ yang tersedia dalam tanah juga berperan dalam fase awal pertumbuhan tanaman jagung yang memperlihatkan tampilan tanaman lebih hijau (Gambar 3).

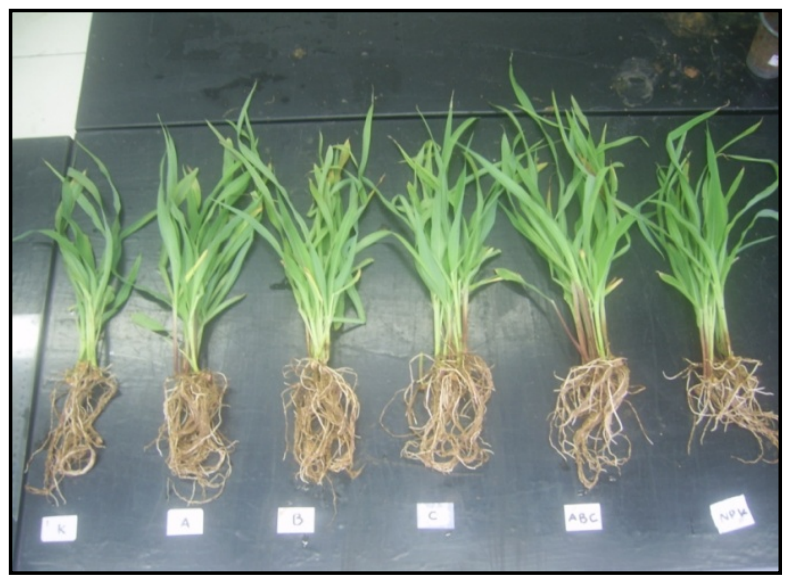

Gambar 3. Tanaman pada fase awal pertumbuhan ketika dipanen
Mikrob fungsional yang terdapat dalam formulasi pupuk hayati seperti pada formula $\mathrm{ABC}$ memungkinkan untuk dapat memproduksi hormon perangsang tumbuh. Bahkan beberapa peneliti meyakini bahwa peranan mikrob fungsional dalam tanah lebih karena kemampuannya dalam memproduksi hormon perangsang tumbuh. LESTARI [17] dalam penelitiannya melaporkan bakteri non-simbiotik Azospirillum Az7 yang digunakan dalam penelitiannya mampu menghasilkan AIA yang berpengaruh baik terhadap perkembangan akar padi. Namun dengan penelitian ini dapat ditunjukkan bahwa mikrob fungsional yang diformulasikan dalam bentuk formula pupuk hayati juga secara positif menyumbangkan $\mathrm{N}$ melalui fiksasi $\mathrm{N}_{2}$ secara nyata.

\section{Pertumbuhan Tanaman Jagung}

Gambar 4 menunjukkan bahwa secara statistik berat kering tanaman jagung meningkat secara nyata $(\mathrm{P}<0,005)$ akibat pemberian perlakuan baik itu pupuk hayati single strain, multi-strain, maupun pupuk rekomendasi penuh $(\mathrm{K}+)$ bila dibandingkan dengan kontrol. Peningkatan berat kering

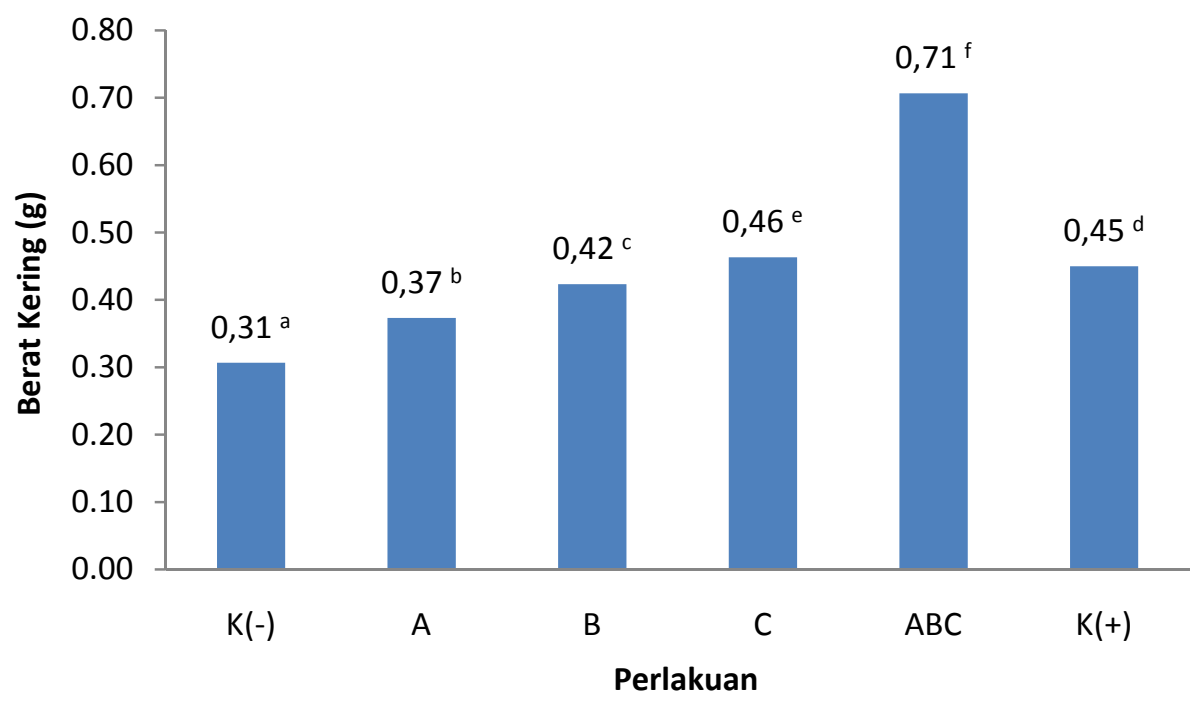

Gambar 4. Pengaruh perlakuan pupuk hayati terhadap berat kering tanaman $(\mathrm{g})$.

Keterangan: Huruf superscript yang berbeda pada kolom yang sama berbeda nyata $(\mathrm{P}<0,05)$. 
tanaman jagung tertinggi diperoleh pada perlakuan pupuk hayati multi strain $(\mathrm{ABC})$ yaitu sebanyak $123,03 \%$ bila dibandingkan dengan kontrol (K-). Respon peningkatan ini diduga sejalan dengan tingginya serapan $\mathrm{N}$ tanaman dari perlakuan ABC. Nitrogen merupakan unsur komponen penyusun klorofil dan juga penyusun utama asam amino dan protein sehingga dengan meningkatnya serapan $\mathrm{N}$ tanaman maka meningkat juga bobot tanaman pada saat pemanenan.

\section{KESIMPULAN}

Dari penelitian yang dilakukan maka dapat disimpulkan bahwa formula pupuk hayati campuran dari Azotobacter vinelandii (A), Bacillus cereus (B), Bacillus megaterium (C) berpengaruh secara nyata $(\mathrm{P}<0,05)$ dalam meningkatkan $\mathrm{N}$ total tanaman pada fase awal pertumbuhan tanaman jagung. Lebih lanjut dengan teknik N-15 dapat diketahui bahwa sumbangan formula pupuk hayati pada fase awal pertumbuhan lebih besar daripada sumbangan $\mathrm{N}$ yang berasal dari tanah. Pupuk hayati campuran ABC telah bekerja secara efektif dalam menyumbangkan $\mathrm{N}$ pada awal pertumbuhan tanaman jagung. Ada indikasi bahwa peran pupuk hayati melalui proses fiksasi $\mathrm{N}$ biologis lebih besar daripada peran dari pupuk hayati sebagai penghasil zat pengatur tumbuh.

\section{DAFTAR PUSTAKA}

1. BIARI A, A. GHOLAMI, H.A. RAHMANI. Growth promotion and enhanced nutrient uptake of maize (Zea mays L.) by application of plant growth promoting Rhizobacteria in arid region of Iran. J. Biological. Sci., 8 (6), 1015-1020 (2006).

2. http://https://www.bps.go.id/linkTableDi namis/view/id/868. diunduh pada tanggal 07 April 2016.
3. SHARMA AK. Biofertilizers for Sustainable Agriculture. Agrobios, India. Shetty. S., Singhal K.S. and Kulkaria P.R. Antimicrobial properties of cumin. J. Microbial Biotech., 10, 230-233 (2003).

4. ORHAN, E., A. ESITKEN, S. ERCISLI, M. TURAN, F. SAHIN. Effects of plant growth promoting rhizobacteria (PGPR) on yield, growth and nutrient contents in organically growing raspberry. Sci. Hortic., 111, 38-43 (2006).

5. HUSSEIN, A. H. A., S. A. SALEH, M. A. EL DEEB, AND W. KADRY. Effect of Rhizobium inoculation, Phosphoras and potassium cultivated in the newly reclaimed soils of middle Egypt. Bulletin of Faculty of Agriclture, University of Cairo, 48 (1), 201-214 (1997).

6. HAMIDI. Agro ecologic aspects of biofertilizers application on grain and grass Silage yield two vessels late corn. PhD thesis, Faculty of Agriculture, university of teacher training. (In Persian) (2006).

7. DE FREITAS JR. Yield and N assimilation of winter wheat (Triticumaestivum L., var. Norstar) inoculated with rhizobacteria. Pedobiologia, 44, 97-104 (2000).

8. VESSEY, J.K. Plant growth promoting rhizobacteria as biofertilizers. Plant Soil, 255, 571-586 (2003).

9. JAHAN, M. Agroecological aspects of corn (Zea mays L.) symbiosis with arbuscular mycorrhizal fungus and free living nitrogen fixing bacteria under ecological and conventional cropping systems. Ph.D. Thesis. Ferdowsi University of Mashhad, Iran (2008). 
10. WU, S.C., CAO, Z.H., LI, Z.G., CHEUNG, K.C., WONG, M.H. Effects of biofertilizer containing $\mathrm{N}$ fixer, $\mathrm{P}$ and $\mathrm{K}$ solubilizers and $\mathrm{AM}$ fungi on maize growth: a green house trial. Geoderma, 125, 155166 (2005).

11. MEHNAZ, S., T. KOWALIK, B. REYNOLDS, G. LAZAROVITZ. Growth promoting effects of corn (Zea mays) bacterial isolates under greenhouse and field conditions. Soil Biol. Biochem. 42, 1848-1856 (2010).

12. FNCA BIOFERTILIZER GROUP. FNCA Guideline for Biofertilizer Quality Assurance and Control. Vol. 1 Quantification of beneficial microbes in biofertilizer. Forum for Nuclear Cooperation in Asia (FNCA). Japan Atomic Industria Forum, Tokyo (2014).

13. GOMEZ, K.A., GOMEZ A.A. Prosedur Statistik Untuk Penelitian Pertanian. Edisi Kedua. Penerjemah Endang Sjamsudin, Justika S. Baharsjah; pendamping Andi Hakim Nasution. Universitas Indonesia Press (1995).
14. EVIATI, SULAEMAN. Analisis Kimia Tanah, Tanaman, Air, dan Pupuk Balai Penelitian Tanah: Balai Besar Litbang Sumber Daya Lahan Pertanian, Badan Penelitian dan Pengembangan Pertanian, Departemen Pertanian, Bogor. (2009).

15. SISWORO, E.L., K. IDRIS, CITRARESMINI A. and SUGORO I. Teknik nuklir untuk penelitian hubungan tanah-tanaman. Perhitungan dan Interpretasi Data, Badan Tenaga Nuklir Nasional. Jakarta (2006).

16. ALEXANDER, M. Introduction to Soil Microbiology, 2nd ed. John Wiley and Sons, New York and London. (1977).

17. YAZDANI, M.A. H. BAHMANYAR, PIRDASHTI, and M.A. ESMAILI. Effect of Phosphate Solubilization Microorganisms (PSM) and Plant Growth Promoting Rhizobacteria (PGPR) on Yield and Yield Components of Corn (Zea mays L.). Proceedings of World Academy of Science, Engineerring and Technology. 3 (7), 90-92 (2009). 